The Spatial Distribution of Alkaloids in Psychotria prunifolia (Kunth) Steyerm and Palicourea coriacea (Cham.) K. Schum Leaves Analysed by Desorption Electrospray Ionisation Mass Spectrometry Imaging

Kato, Lucilia; Moraes, Aline Pereira; de Oliveira, Cecília Maria Alves; Vaz, Boniek Gontijo; de Almeida Gonçalves, Letícia; E Silva, Elienai Cândida; Janfelt, Christian

Published in:

Phytochemical Analysis

DOI:

10.1002/pca. 2715

Publication date:

2018

Document version

Publisher's PDF, also known as Version of record

Document license:

Unspecified

Citation for published version (APA):

Kato, L., Moraes, A. P., de Oliveira, C. M. A., Vaz, B. G., de Almeida Gonçalves, L., E Silva, E. C., \& Janfelt, C. (2018). The Spatial Distribution of Alkaloids in Psychotria prunifolia (Kunth) Steyerm and Palicourea coriacea (Cham.) K. Schum Leaves Analysed by Desorption Electrospray lonisation Mass Spectrometry Imaging. Phytochemical Analysis, 29, 69-76. https://doi.org/10.1002/pca.2715 


\title{
The Spatial Distribution of Alkaloids in Psychotria prunifolia (Kunth) Steyerm and Palicourea coriacea (Cham.) K. Schum Leaves Analysed by Desorption Electrospray Ionisation Mass Spectrometry Imaging
}

\author{
Lucilia Kato, ${ }^{a *} \odot$ Aline Pereira Moraes, ${ }^{a} \oplus$ Cecília Maria Alves de Oliveira, ${ }^{a}$

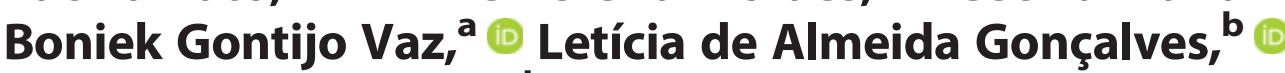 \\ Elienai Cândida e Silva ${ }^{b}{ }^{\oplus}$ and Christian Janfelt ${ }^{c}{ }^{\circledR}$
}

\begin{abstract}
:
Introduction - Species of the genera Psychotria and Palicourea are sources of indole alkaloids, however, the distribution of alkaloids within the plants is not known. Analysing the spatial distribution using desorption electrospray ionisation mass spectrometry imaging (DESI-MSI) has become attractive due to its simplicity and high selectivity compared to traditional histochemical techniques.

Objectives - To apply DESI-MSI to visualise the alkaloid distribution on the leaf surface of Psychotria prunifolia and Palicourea coriacea and to compare the distributions with HPLC-MS and histochemical analyses.

Methodology - Based upon previous structure elucidation studies, four alkaloids targeted in this study were identified using high resolution mass spectrometry by direct infusion of plant extracts, and their distributions were imaged by DESI-MSI via tissue imprints on a porous Teflon surface. Relative quantitation of the four alkaloids was obtained by HPLC-MS/MS analysis performed using multiple-reaction monitoring (MRM) mode on a triple quadrupole mass spectrometer.

Results - Alkaloids showed distinct distributions on the leaf surfaces. Prunifoleine was mainly present in the midrib, while 10hydroxyisodeppeaninol was concentrated close to the petiole; a uniform distribution of 10-hydroxyantirhine was observed in the whole leaf of Psychotria prunifolia. The imprinted image from the Palicourea coriacea leaf also showed a homogeneous distribution of calycanthine throughout the leaf surface.

Conclusion - Different distributions were found for three alkaloids in Psychotria prunifolia, and the distributions found by MSI were in complete accordance with HPLC-MS analysis and histochemical results. The DESI-MSI technique was therefore demonstrated to provide reliable information about the spatial distribution of metabolites in plants. Copyright $\odot 2017$ John Wiley \& Sons, Ltd.
\end{abstract}

Keywords: DESI-MSI; alkaloids; Rubiaceae; imaging

\section{Introduction}

Psychotria L. and Palicourea Aubl. (Rubiaceae) species are used in Brazilian folk medicine to treat several types of diseases (Delprete, 2010; Yang et al., 2016). The Psychotria genus, which comprises approximately 1600 species, is widely acknowledged as a source of indole alkaloids as well as for its traditional indigenous use as a hallucinogenic beverage (Rivier and Lindgren, 1972). According to a recent review, $60 \%$ of the different metabolites isolated from Psychotria species are alkaloids, of which $87 \%$ are indole alkaloids (Klein-Junior et al., 2014). In a previous study of Psychotria prunifolia, five indole alkaloids were isolated and among these the prunifoleine (1) and 14-oxoprunifoleine (2) showed inhibitory activity in a time-dependent mechanism against monoamino oxidase (MAO-A), acetylcholinesterase (AchE), and butyrycholinesterase ( $\mathrm{BChE}$ ) which are target enzymes in the treatment of neurodegenerative disorders such as Parkinson's and Alzheimer's diseases (Passos et al., 2013).
The genus Palicourea comprises approximately 600 species (Taylor, 2015). Palicourea coriacea (Cham.) K. Shum is known to contain the alkaloid calycanthine (5), glucoindole alkaloids such as 3-epi-strictosidinic acid and derivatives, ursolic acid and benzoyl and cinnamoyl derivatives (do Nascimento et al., 2006; da Silva et al., 2008).

\footnotetext{
* Correspondence to: Lucília Kato, P.O. Box: 24222, Universidade Federal de Goiás, Campus II, 74690-970, Goiânia, Goiás, Brazil.

Email: lucilia@ufg.br

a Instituto de Química, Universidade Federal de Goiás, Campus Samambaia, Goiânia, 74690-900, Goiás, Brazil

b Instituto de Ciências Biológicas, Universidade Federal de Goiás, Campus Samambaia, Goiânia, 74690-900, Goiás, Brazil

Department of Pharmacy, University of Copenhagen, Universitetsparken 2, 2100, Copenhagen, Denmark
} 
Phytochemical studies on Palicourea or Psychotria in recent years have further contributed to ethnobotanical, pharmacological and chemotaxonomic research (Calixto et al., 2016; Yang et al., 2016). However, the spatial distribution of alkaloids in the leaves or any part of the plant is not known in these genera.

In the present study, the distributions of three alkaloids in leaves of Psychotria prunifolia and one alkaloid in leaves of Palicourea coriacea were analysed by indirect desorption electrospray ionisation mass spectrometry imaging (DESI-MSI) (Takáts et al., 2004). Standard histochemical staining techniques for alkaloids and HPLC-MS/MS analyses were used to validate the results obtained by DESI-MSI.

\section{Experimental}

\section{Plant material}

Forty-five fresh leaves of Psychotria prunifolia and Palicourea coriacea were collected at Bosque Saint-Hilaire in Goiás state, Brazil, in December. The leaves were placed in Falcon tubes with a piece of cotton soaked with water (three leaves per tube), and shipped to the Department of Pharmacy, University of Copenhagen where they were stored at $-80^{\circ} \mathrm{C}$ until analysis. The voucher specimens of the Psychotria prunifolia and Palicourea coriacea were deposited at the herbarium of the Universidade Federal de Goiás (UFG) with numbers 10323 and 27153, respectively. The leaves were collected from a single adult plant of each taxon. Collection and transport were

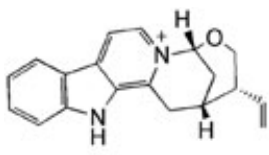

1

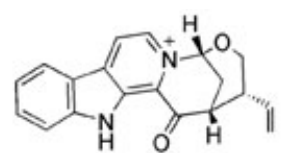

2

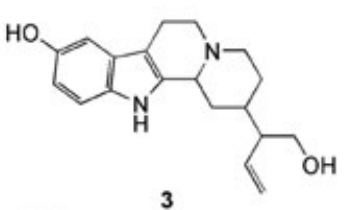<smiles>C=CC(CO)C(CCO)Cc1nccc2c1[nH]c1ccc(O)cc12</smiles>

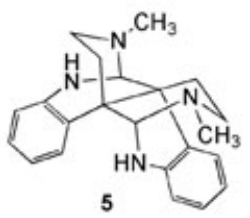

Figure 1. Structures of the alkaloids observed in this study: (1) $\left(M^{+}=m / z 291\right)$ prunifoleine, (2) 14-oxoprunifoleine, $(\mathbf{3})\left([M+H]^{+}=m / z 313\right) 10-$ hydroxyantirhine; (4) $\left([\mathrm{M}+\mathrm{H}]^{+}=\mathrm{m} / \mathrm{z}\right.$ 327) 10 -hydroxyisodeppeaninol and (5) $\left([\mathrm{M}+\mathrm{H}]^{+}=\mathrm{m} / \mathrm{z} 347\right)$ calycanthine.

Table 1. Detected and imaged alkaloids from Psychotria prunifolia and Palicourea coriacea leaves by mass spectrometry

\begin{tabular}{|c|c|c|c|c|c|c|c|c|}
\hline Alkaloid & Plant & $\begin{array}{l}\text { Molecular } \\
\text { formula }\end{array}$ & $\begin{array}{l}\text { lon } \\
\text { mode }\end{array}$ & $\begin{array}{c}m / z \\
\text { (observed) }\end{array}$ & $\begin{array}{c}m / z \\
\text { (calculated) }\end{array}$ & $\begin{array}{l}\text { Error } \\
(\mathrm{ppm})\end{array}$ & $\begin{array}{c}\text { MS/MS } \\
(\mathrm{m} / \mathrm{z})\end{array}$ & Reference \\
\hline Prunifoleine & $\begin{array}{l}\text { Psychotria } \\
\text { prunifolia }\end{array}$ & $\mathrm{C}_{19} \mathrm{H}_{19} \mathrm{~N}_{2} \mathrm{O}^{+}$ & {$[\mathrm{M}]^{+}$} & 291.1491 & 291.1492 & -0.3 & $\begin{array}{c}261.1387 \\
237.1023 \\
219.0918 \\
182.0840\end{array}$ & (Faria et al., 2010) $^{a}$ \\
\hline 10-Hydroxyantirhine & $\begin{array}{l}\text { Psychotria } \\
\text { prunifolia }\end{array}$ & $\mathrm{C}_{19} \mathrm{H}_{24} \mathrm{~N}_{2} \mathrm{O}_{2}$ & {$[\mathrm{M}+\mathrm{H}]^{+}$} & 313.1908 & 313.1910 & -0.6 & $\begin{array}{c}296.1644 \\
160.0756 \\
154.1226\end{array}$ & (Kato et al., 2012) $^{a}$ \\
\hline 10-Hydroxyisodeppeaninol & $\begin{array}{l}\text { Psychotria } \\
\text { prunifolia }\end{array}$ & $\mathrm{C}_{19} \mathrm{H}_{22} \mathrm{~N}_{2} \mathrm{O}_{3}$ & {$[\mathrm{M}+\mathrm{H}]^{+}$} & 327.1703 & 327.1703 & $<0.1$ & 309,295 & $($ Kato et al., 2012) \\
\hline calycanthine & $\begin{array}{r}\text { Palicourea } \\
\text { coriacea }\end{array}$ & $\mathrm{C}_{22} \mathrm{H}_{26} \mathrm{~N}_{4}$ & {$[\mathrm{M}+\mathrm{H}]^{+}$} & 347.2230 & 347.2230 & $<0.1$ & $\begin{array}{l}316,290 \\
285,173\end{array}$ & (Zhang et al., 2009) \\
\hline
\end{tabular}
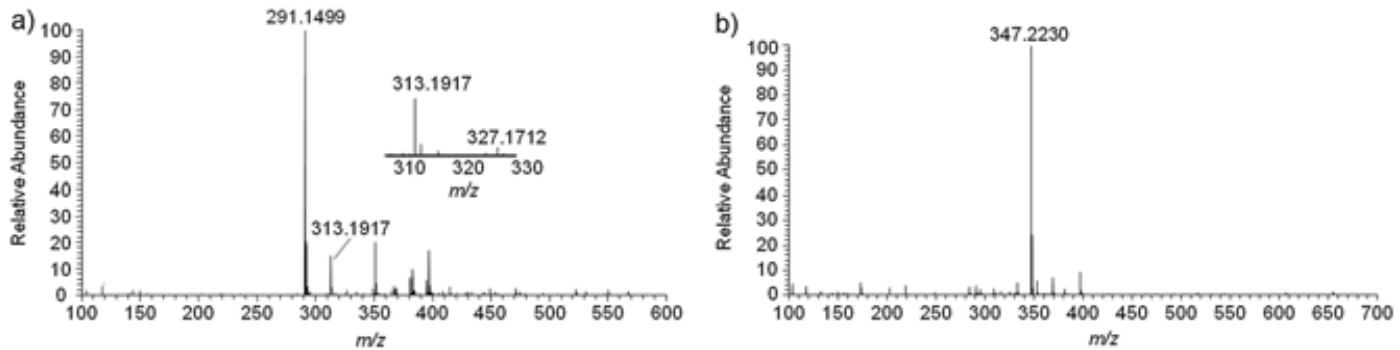

Figure 2. ESI-(+)-HRMS spectra of methanolic extract of (a) Psychotria prunifolia and (b) Palicourea coriacea leaves. [Colour figure can be viewed at wileyonlinelibrary.com] 
authorised by the Brazilian government through Conselho de Gestão do Patrimônio Genético (CGEN - process register number 010742/2014-0).

\section{Chemicals}

HPLC-MS grade methanol and chloroform were purchased from Th. Geyer (Roskilde, Denmark), and formic acid (ACS reagent, 99\%) was purchased from Sigma-Aldrich (Copenhagen, Denmark). Porous Teflon (1.5 mm thick, medium pore size $7 \mathrm{~mm}$, pore volume 36\%) was purchased from Berghof (Eningen, Germany).

\section{Sample preparation for DESI-MSI experiment}

Samples were prepared following the protocol of Janfelt (2015). Briefly, the porous Teflon was washed twice using a few drops of methanol and placed in a desiccator for $5 \mathrm{~min}$. For imprinting, a sandwich was made with the fresh leaf on a clean piece of porous Teflon (abaxial side facing the Teflon) and covered with tissue paper (for absorption of surplus plant juice) and a thin rubber mat $(20 \mathrm{~mm} \times 50 \mathrm{~mm} \times 1 \mathrm{~mm}$ ) (to distribute the pressure over the entire piece of the sample material). It was mounted in a vice and pressed for $10 \mathrm{~s}$. The resultant Teflon imprints were dried in a vacuum desiccator for $1 \mathrm{~min}$ and analysed by DESI-MSI immediately afterwards.

\section{DESI-MS imaging analysis}

DESI-MS imaging was carried out on a Thermo Scientific LTQ XL linear ion trap mass spectrometer (Thermo Scientific, San Jose, CA, USA) equipped with a custom-built DESI imaging ion source. The latter was based on a motorised microscope stage from Märzhäuser Wetzlar (Wetzlar, Germany) and controlled by an in-house written software as described in detail elsewhere (Thunig et al., 2011). Mass spectra were collected with Xcalibur 2.0 software (Thermo Fisher Scientific) and converted to imzML files (Schramm et al., 2012). Images were generated with Data Cube Explorer from AMOLF, Amsterdam (Klinkert et al., 2014). The MS instrumental parameters used were as follows: 5 bar nebuliser gas $\left(\mathrm{N}_{2}\right)$ pressure, $300^{\circ} \mathrm{C}$ heated capillary temperature, $5 \mathrm{kV}$ spray voltage, $30 \mathrm{~V}$ capillary voltage, and $70 \mathrm{~V}$ tube lens voltage. The ion injection time was $100 \mathrm{~ms}$ (AGC off), and five microscans were averaged for each pixel in the image. A mixture of methanol/water (70:30, v/v) was used as the spray solvent and delivered at a flow rate of $5 \mu \mathrm{L} / \mathrm{min}$. Mass spectra were acquired in full-scan positive ion mode with a scan range $\mathrm{m} / \mathrm{z} 250-500$. The surface was scanned with a speed of $0.429 \mathrm{~mm} / \mathrm{s}$, providing a pixel size of $300 \mu \mathrm{m}$. Reproducibility of the presented results was ensured by performing imaging on at least five individual leaves of each type.

\section{Identification of metabolites by high-resolution MS by direct infusion and DESI MS/MS analysis}

Half lateral of a leaf of each species was cut in small $(c .2 \mathrm{~cm} \times 2 \mathrm{~cm})$ pieces and extracted in methanol (c. $2 \mathrm{~mL}$ ) for approximately $5 \mathrm{~min}$ at room temperature. An aliquot $(100 \mu \mathrm{L})$ of the supernatant was diluted in methanol $(900 \mu \mathrm{L})$. The sample was filtered (Millex HV, PVDF, Merck Millipore, Darmstadt, Germany) and infused into the electrospray ionisation (ESI) source of a Thermo Q-Exactive Orbitrap mass spectrometer (Thermo Scientific), using a Hamilton $500 \mu \mathrm{L}$ syringe at a flow rate of $0.5 \mu \mathrm{L} / \mathrm{min}$. ESI-MS analysis was performed in positive mode with capillary temperature $350^{\circ} \mathrm{C}$, ionisation voltage $3.3 \mathrm{kV}$ and resolution 140000 . Mass to charge ratios were obtained with a mass accuracy of $\leq 3 \mathrm{ppm}$. For prunifoleine (1) and 10hydroxyantirhine (3) MS/MS analysis was performed on the Q-Exactive. For 10-hydroxyisodeppeaninol (4) the signal intensity in these experiments was insufficient for good MS/MS analysis, and therefore MS/MS for 10hydroxyisodeppeaninol (4) was performed as part of the ion trap DESI-MS experiments described earlier.

\section{Sample preparation for relative quantitation of alkaloids by HPLC-ESI-(+)-MS/MS analysis}

The central midrib of the leaf was dissected from leaves. The midrib and the rest of the leaves were separated, frozen in liquid nitrogen and ground in a a)

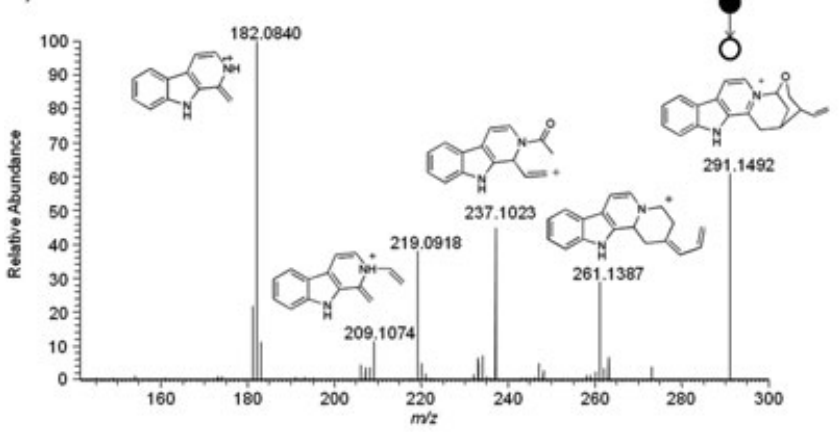

c)

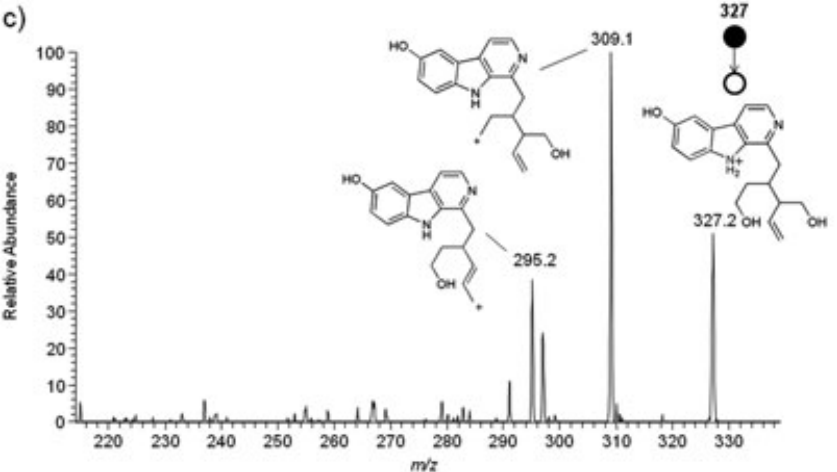

b)

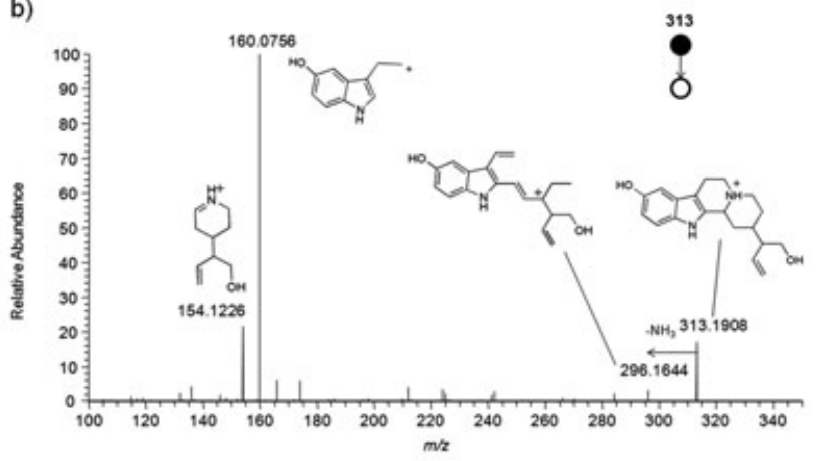

d)

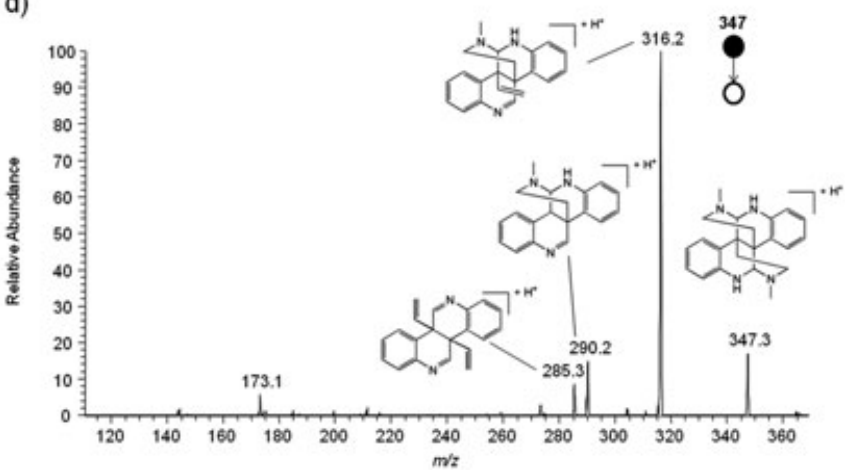

Figure 3. ESI-(+)-HRMS/MS spectra of (a) prunifoleine ( $\mathrm{m} / \mathrm{z}$ 291.1942), (b) 10-hydroxyantirhine ( $\mathrm{m} / \mathrm{z}$ 313.1917); and DESI-(+)-MS/MS of (c) 10hydroxyisodeppeaninol $(\mathrm{m} / \mathrm{z} 327)$ and (d) calycanthine $(\mathrm{m} / \mathrm{z} 347)$. 
mortar. The resulting powder was freeze-dried (c. $3 \mathrm{mg}$ of each sample) and extracted in a boiling refluxing $85 \%$ methanol in water $(2.5 \mathrm{~mL})$ for $3 \mathrm{~min}$. Then, an aliquot $(500 \mu \mathrm{L}$ ) of each solution was centrifuged (at $12000 \mathrm{rpm}$ for $5 \mathrm{~min}$ ) and an aliquot (100 $\mu \mathrm{L}$ ) of the supernatant was diluted in methanol $(900 \mu \mathrm{L})$. The solution was filtered through a $0.45 \mu \mathrm{m}$ syringe filter (Millex HV, PVDF, Merck Millipore).

\section{Relative quantitation of alkaloids by HPLC-ESI(+)MS/MS analysis}

HPLC-MS/MS was performed in triplicate on a Thermo-Finnigan TSQ Quantum mass spectrometer (Thermo Scientific) equipped with a Thermo Accela HPLC system. The column was a Phenomenex Kinetex 2.6u C18 $50 \times 2.10 \mathrm{~mm}$, and separation was performed with gradient elution using $0.1 \%$ formic acid in Milli-Q water as mobile phase $\mathrm{A}$ and methanol with $0.1 \%$ formic acid added as mobile phase $B$ with a flow rate of $0.2 \mathrm{~mL} / \mathrm{min}$. The mobile phase B was raised from $30 \%$ to $70 \%$ B over 4 min, followed by re-equilibration at $30 \% \mathrm{~B}$ for $3 \mathrm{~min}$. The ESI spray voltage was $4 \mathrm{kV}$ in positive ion mode, sheath gas pressure 30 (arbitrary units), auxiliary gas pressure 10 (arbitrary units), ion sweep gas pressure 0 , ion transfer capillary temperature $270^{\circ} \mathrm{C}$ and skimmer offset $0 \mathrm{~V}$.

The compounds present in the plant extracts were monitored by tandem mass spectrometry in the multiple-reaction monitoring (MRM) mode using the following MS/MS transitions during the entire chromatographic run. For Psychotria prunifolia: prunifoleine (1) $(m / z \quad 291 \rightarrow$ 237); 10-hydroxyantirhine $(3)(\mathrm{m} / \mathrm{z} 313 \rightarrow 160)$ and 10-hydroxyisodeppeaninol (4) $(\mathrm{m} / z \quad 327 \rightarrow 295)$ and for Palicourea coriacea: calycanthine
(5) ( $m / z$ 347-316). The alkaloid contents were assessed for statistically significant differences by one-tailed Student's $t$ tests using GraphPad InStat 3 (GraphPad Software Inc, San Diego, CA, USA).

\section{Histochemical analyses}

The leaves for histochemical analyses were identified and collected in the wild from the same individual Psychotria prunifolia as used for MSI analysis. The fresh leaves were stored at $+5^{\circ} \mathrm{C}$ for $4 \mathrm{~h}$. Fully expanded leaves from the second to third node (from apex to base) were used. Leaf fragments $(10 \mathrm{~mm} \times 15 \mathrm{~mm})$ were collected from the apical, middle third, basal, leaf blade, and petiole areas. The samples were free-handed cut transversely using a scalpel and stained using Wagner's reagent (Furr and Mahlberg, 1981), and photomicrographs of the sections were taken using a Leica ICC50 HD microscope camera attached to a Leica DM500 optical microscope. The LAS EZ software, version 1.8.1 was used for image acquisition (Leica Microsystems $\mathrm{GmbH}$, Heerbrugg, Switzerland). These assays were performed at the Biological Sciences Department at UFG (Brazil).

\section{Results and discussion}

\section{Identification of alkaloids}

To confirm the identity of alkaloids present and previously identified (Faria et al., 2010; do Nascimento et al., 2006) in Psychotria

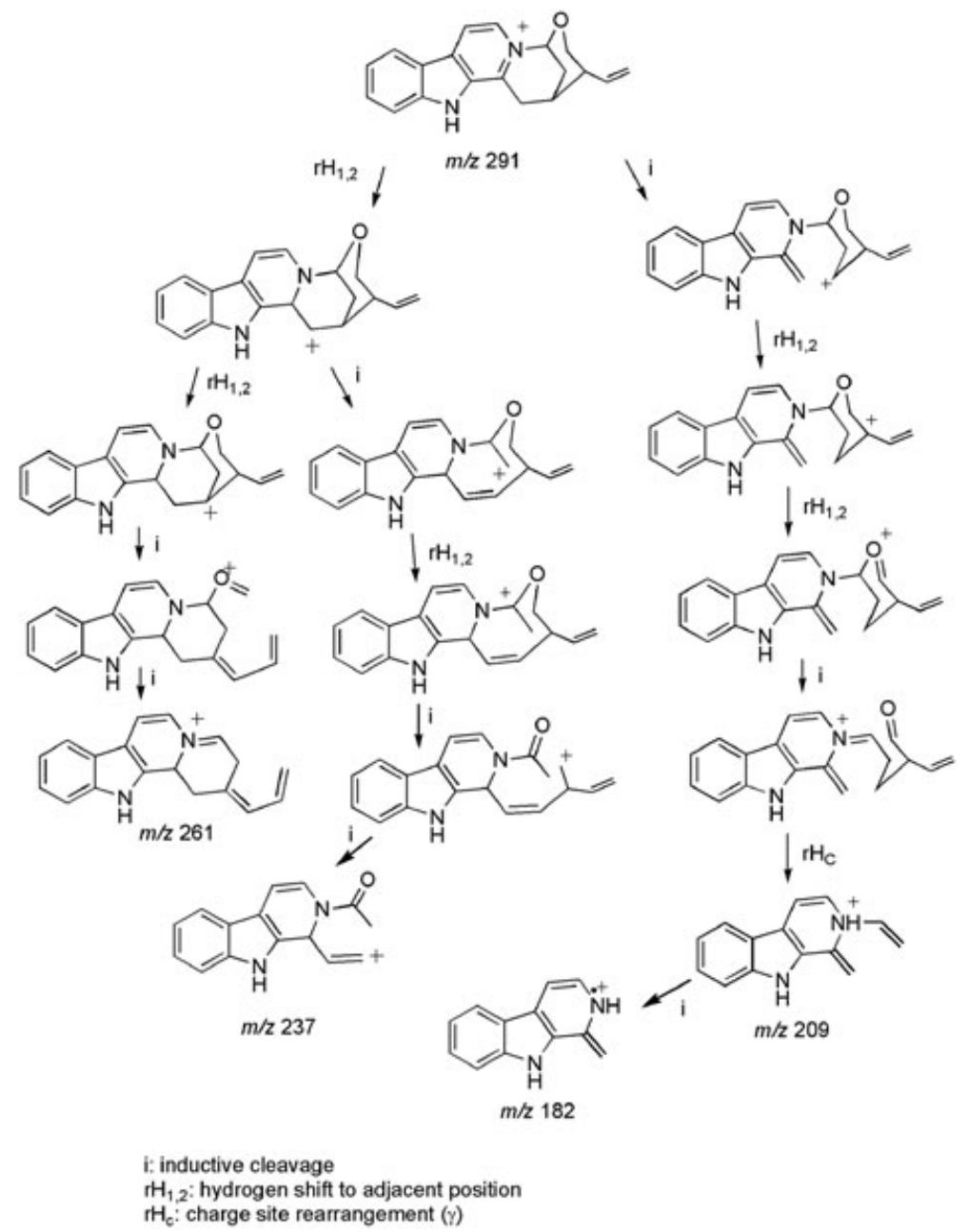

Figure 4. Molecular ion fragmentation pattern proposed for alkaloid 1 by DESI-MS/MS. 
prunifolia and Palicourea coriacea leaves (Fig. 1; Table 1), the methanol extract from their leaves were analysed by direct infusion into an Orbitrap mass spectrometer (Fig. 2). The HRESI-(+)-MS of Psychotria prunifolia (Fig. 2a) is mainly characterised by the ion at $\mathrm{m} / \mathrm{z} 291.1499$, corresponding to the molecular ion of prunifoleine (1), whereas the HRESI-(+)-MS of Palicourea coriacea (Fig. 2b) presents a major peak at $\mathrm{m} / \mathrm{z}$ 347.2230 $[\mathrm{M}+\mathrm{H}]^{+}$, identified as calycanthine (5). These compounds correspond to the most abundant alkaloids previously isolated from their respective leaves.

In addition, two less intense signals were observed in the HRESI-(+)-MS of Psychotria prunifolia at $\mathrm{m} / \mathrm{z} 313.1917$ and 327.1712 , attributed to $[\mathrm{M}+\mathrm{H}]^{+}$of 10 -hydroxyantirhine (3) and to $[\mathrm{M}+\mathrm{H}]^{+}$of 10 -hydroxyisodeppeaninol (4), respectively. The NMR spectra details of these alkaloids are described elsewhere (Faria et al., 2010; Kato et al., 2012; do Nascimento et al., 2006), but MS/MS fragmentation data for these alkaloids (Figs 3-6) have not previously been presented.

The ESI-(+)-MS/MS spectrum of molecular ion $1\left(\mathrm{M}^{+} \mathrm{m} / \mathrm{z}\right.$ 291.1492, Fig. 3a) contains fragments of $\mathrm{m} / \mathrm{z} 261.1387$ of $\left[\mathrm{C}_{18} \mathrm{H}_{17} \mathrm{~N}_{2}\right]^{+}$from the loss of $\mathrm{CH}_{2} \mathrm{O}$ and $\mathrm{m} / \mathrm{z} 237.1023$ of $\left[\mathrm{C}_{15} \mathrm{H}_{13} \mathrm{~N}_{2} \mathrm{O}\right]^{+}$from the loss of a butadiene molecule $\left(-\mathrm{C}_{4} \mathrm{H}_{6}\right)$ (Fig. 4). The ESI-(+)-MS/MS spectrum of protonated molecule 3 $\left([\mathrm{M}+\mathrm{H}]^{+}\right.$at $m / z$ 313.1908, Fig. 3b) contains the $m / z 296.1644$ fragment from the loss of $\mathrm{NH}_{3}$. Alternatively, the precursor ion can lose

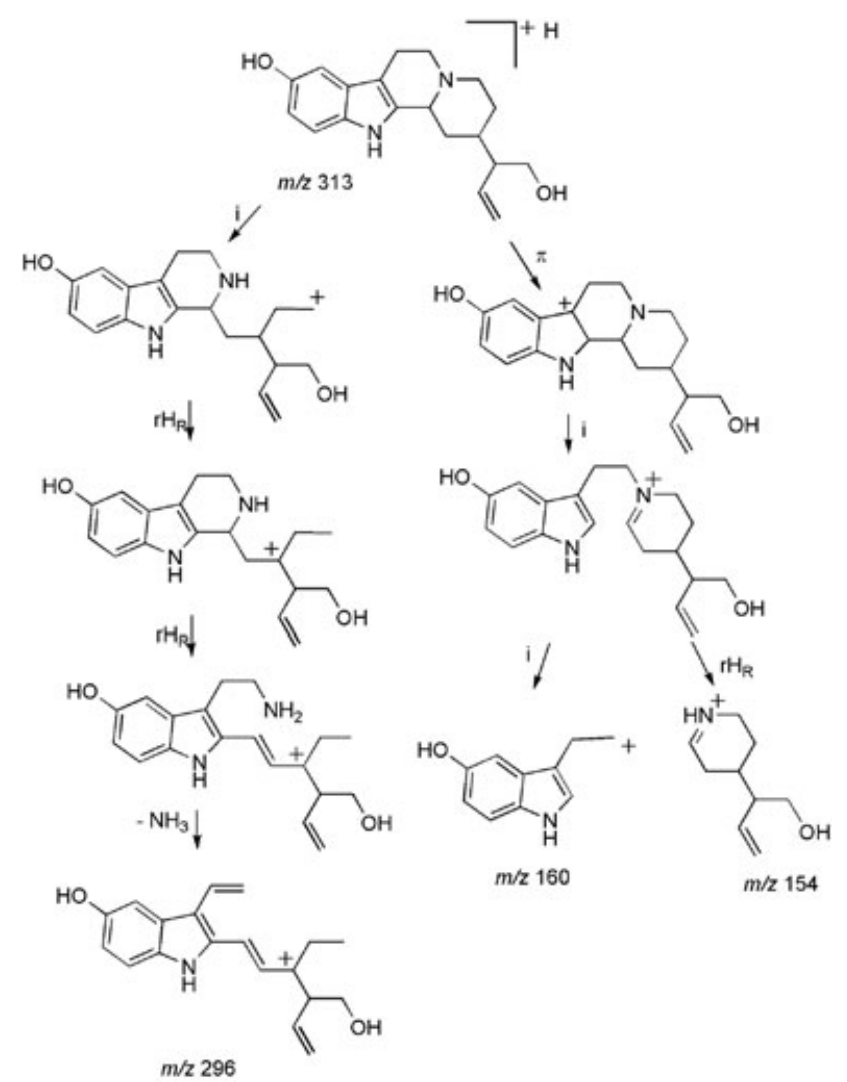

i: inductive cleavage

$\pi: \pi$ electron ionization

$\mathrm{rH}_{\mathrm{R}}$ : charge-remote rearrangement

Figure 5. Protonated ion fragmentation pattern proposed for alkaloid 3 by DESI-MS/MS.

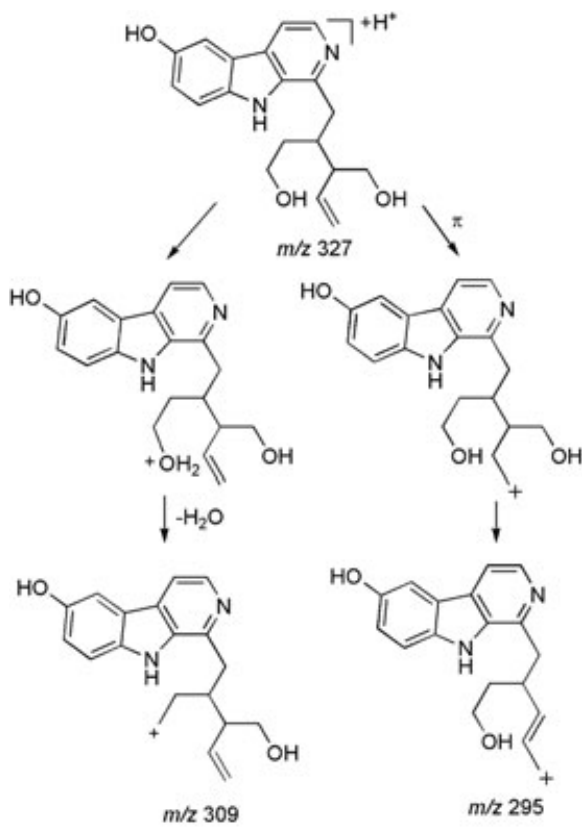

$\pi ; \pi$ electron ionization

Figure 6. Protonated ion fragmentation pattern proposed for alkaloid 4 by DESI-MS/MS.

$\mathrm{C}_{9} \mathrm{H}_{15} \mathrm{NO}$ to form the cation $\left[\mathrm{C}_{10} \mathrm{H}_{10} \mathrm{NO}\right]^{+}$at $\mathrm{m} / \mathrm{z} 160.0756$ or lose $\mathrm{C}_{10} \mathrm{H}_{9} \mathrm{NO}$ to form the cation $\left[\mathrm{C}_{9} \mathrm{H}_{16} \mathrm{NO}\right]^{+}$at $\mathrm{m} / \mathrm{z} 154.1226$ (Figs $3 \mathrm{~b}$ and 5).

Due to ion suppression, the less intense signal at $\mathrm{m} / \mathrm{z} 327$ was not stable enough for high resolution fragmentation mass spectra to be recorded. Therefore, the DESI-(+)-MS/MS spectrum of protonated molecule $4\left([\mathrm{M}+\mathrm{H}]^{+} \mathrm{m} / \mathrm{z} 327\right.$, Fig. 3c), obtained prior to the imaging experiment, was used to identify the alkaloid 10-hydroxyisodeppeaninol, which showed fragments $\left[\mathrm{C}_{19} \mathrm{H}_{21} \mathrm{~N}_{2} \mathrm{O}_{2}\right]^{+}$at $\mathrm{m} / \mathrm{z} 309$ and $\left[\mathrm{C}_{18} \mathrm{H}_{19} \mathrm{~N}_{2} \mathrm{O}_{2}\right]^{+}$at $\mathrm{m} / \mathrm{z} 295$ from the loss of $\mathrm{H}_{2} \mathrm{O}$ and $\mathrm{CH}_{3} \mathrm{OH}$, respectively (Fig. 6).

The DESI-(+)-MS/MS spectrum of protonated molecule $\mathbf{5}$ $\left([\mathrm{M}+\mathrm{H}]^{+} \mathrm{m} / \mathrm{z}\right.$ 347, Fig. 3d), also obtained prior to the imaging experiment, contains fragments $\left[\mathrm{C}_{21} \mathrm{H}_{22} \mathrm{~N}_{3}\right]^{+}$at $\mathrm{m} / \mathrm{z} 316$ and $\left[\mathrm{C}_{19} \mathrm{H}_{20} \mathrm{~N}_{3}\right]^{+}$at $\mathrm{m} / \mathrm{z} 290$ from the losses of $\mathrm{CH}_{3} \mathrm{NH}_{2}$ and $\mathrm{CH}_{3} \mathrm{NH}_{2}+\mathrm{C}_{2} \mathrm{H}_{2}$, respectively, in accordance with data from the literature (Zhang et al., 2009).

\section{DESI-MS imaging of leaf tissue}

Figure 7 shows the optical image and indirect DESI-MS images of an imprint of a Psychotria prunifolia leaf, revealing the distributions of the alkaloids prunifoleine (1, $\mathrm{m} / \mathrm{z}$ 291, Fig. 7c), 10-hydroxyantirhine $\quad(3, \mathrm{~m} / \mathrm{z} \quad 313$, Fig. 7d), and 10hydroxyisodeppeaninol $(\mathbf{4}, \mathrm{m} / \mathrm{z} 327$, Fig. 7e) as well as of sucrose $(\mathrm{m} / \mathrm{z}$ 381, Fig. 7f). The alkaloids prunifoleine (1) and 10hydroxyisodeppeaninol (4) appear to be more abundant in the midrib, the latter concentrated close to the petiole, and a uniform distribution of 10-hydroxyantirhine (3) can be observed in the entire leaf. The imprinted image of the Palicourea coriacea leaf (Fig. 8c) also shows the homogeneous distribution of calycanthine (5) throughout the leaf, with less abundance in the midrib, which 

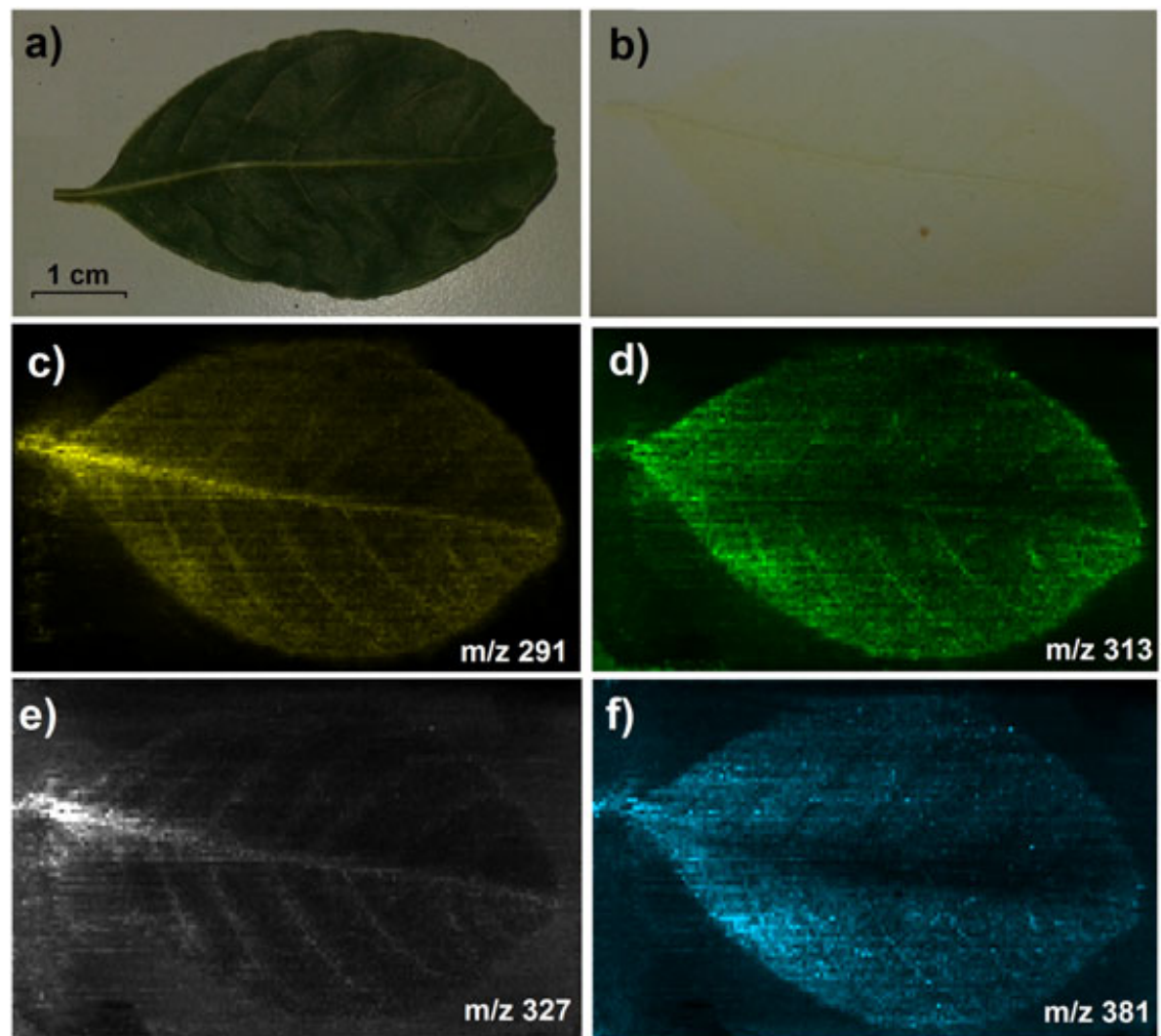

Figure 7. (a) Photography of Psychotria prunifolia leaf after imprint; (b) imprint in Teflon from Psychotria prunifolia leaf, (c)-(f) DESI-MS images of the ions of $\mathrm{m} / \mathrm{z} 291=$ [prunifoleine $]^{+}, \mathrm{m} / \mathrm{z} 327=[10 \text {-hydroxyisodeppeaninol }+\mathrm{H}]^{+}, \mathrm{m} / \mathrm{z} 313=[10 \text {-hydroxyantirhine }+\mathrm{H}]^{+}$and $m / z 381=[\text { sucrose }+\mathrm{K}]^{+}$. [Colour figure can be viewed at wileyonlinelibrary.com]
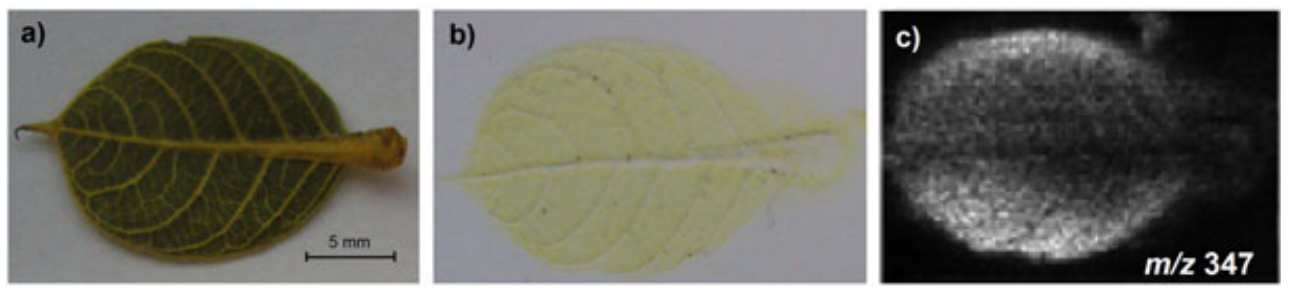

Figure 8. (a) Photography of Palicourea coriacea leaf after imprint; (b) imprint in Teflon from Palicourea coriacea leaf; (c) DESI-MS image of the ion $m / z$ $347=$ [calycanthine $+\mathrm{H}]^{+}$of Palicourea coriacea. [Colour figure can be viewed at wileyonlinelibrary.com]

could suggest that this alkaloid is produced in the leaf and is not transported within the plant.

\section{Histochemical analyses}

Histochemical analyses of the Psychotria prunifolia leaf revealed the presence of alkaloids in a brown region dyed by Wagner's reagent, mainly in the epidermis, collenchyma, main vascular bundle, and parenchyma cells from the central midrib of the leaf blade (Fig. 9A-F) and the petiole (Fig. 9G-H), confirming the localisation of alkaloids imaged by DESI-MSI. Such comparison of MSI analysis and classical histochemical staining has not previously been presented for plant tissue.

\section{Relative quantitation of alkaloids by HPLC-ESI(+)MS/MS analysis}

DESI-MSI shows the differential localisation of alkaloids on the leaf surface, where the petiole and the midrib revealed a more abundant content of prunifoleine $(1, \mathrm{~m} / \mathrm{z} 291)$ and 10hydroxyisodeppeaninol (4, $\mathrm{m} / \mathrm{z}$ 327) compared to the whole leaf. Since MS imaging is normally only a semi-quantitative technique (Lee et al., 2012), the alkaloid contents of Psychotria prunifolia were analysed by HPLC-MS for determination of relative alkaloid contents in methanol extracts from the midrib and the remaining leaf tissue.

Since no pure standards were available for absolute quantitation, the LC-MS/MS results are expressed as relative peak areas 


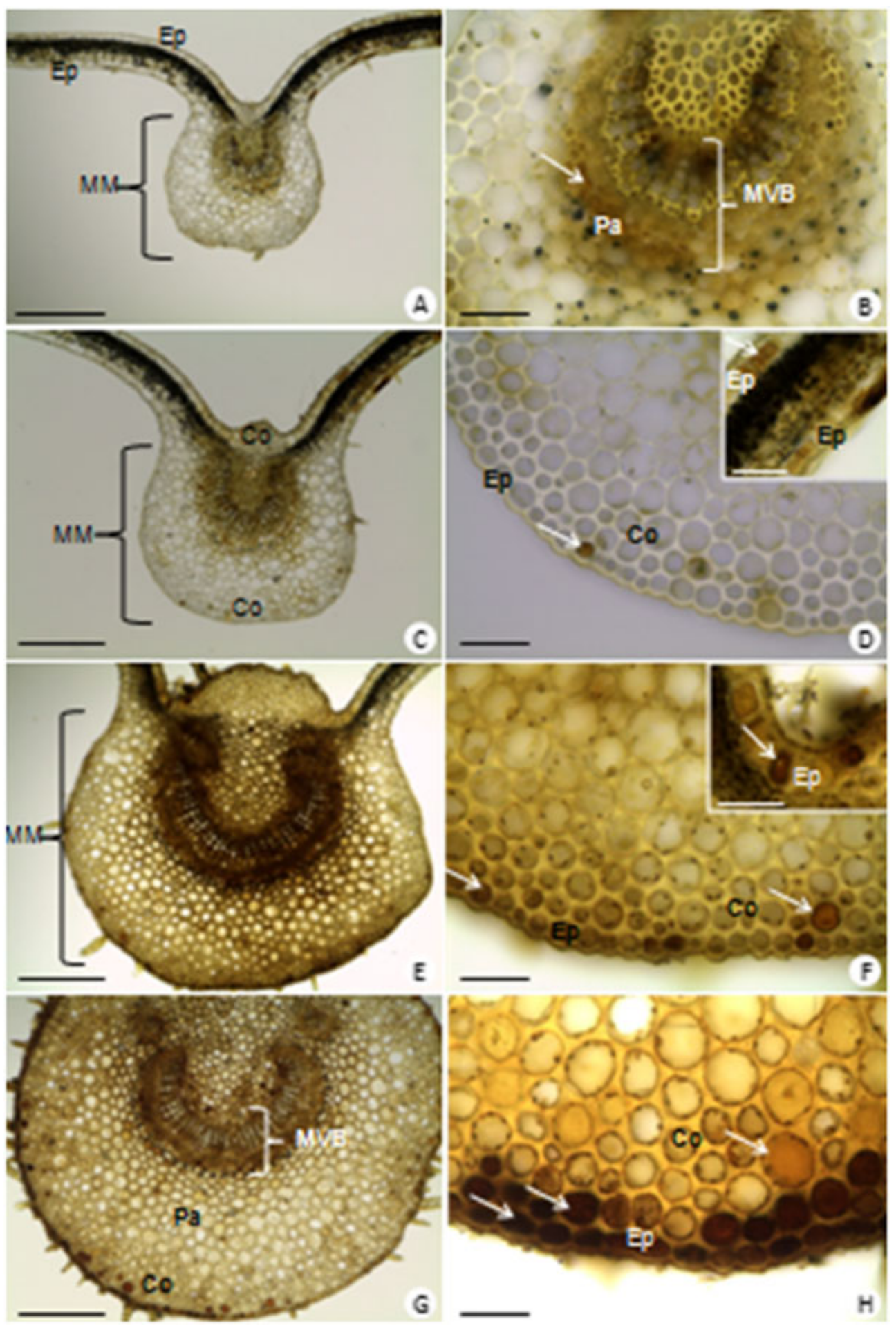

Figure 9. The transversal section of the leaf $(A)-(F)$ and petiole (G)-(H) of Psychotria prunifolia under Wagner's assay. (A)-(B), (C)-(D), and (E)-(F) show apical, medial and basal regions, respectively. Inserts in (D) and (F): show details of epidermal cells (Ep). MM = main midrib; $E p=e p i d e r m ; C o=c o l l e n c h y m a ; ~ V T=$ vascular tissue. $M V B=$ main vascular bundle. Arrow = positive result for alkaloid. Scale bar: $A, C, E$ and G $=500 \mu m . B, D, F$ and $H=100 \mu m$. The brown region dyed by Wagner's reagent indicates the presence of the alkaloids in these cells. [Colour figure can be viewed at wileyonlinelibrary.com]

(adjusted for the amount of leaf tissue used for extraction) of the different alkaloids found in the extracts of the two types of leaf tissue. Statistical analyses of the mean differences in alkaloid content between midrib and leaves analysed by LC-MS (Fig. 10a) showed a higher abundance of prunifoleine $(\mathbf{1}, \mathrm{m} / \mathrm{z} 291)$ and $10-$ hydroxyisodeppeaninol $(\mathbf{4}, \mathrm{m} / \mathrm{z}$ 327) (per gram of dried vegetal material) in the midrib than in the remaining leaf, as well as no significant difference for 10-hydroxyantirhine (3, m/z 313). For the alkaloid calycanthine from Palicourea coriacea, the content in the midrib was significantly lower than in the lamina leaf. The relative peak areas were converted to a percentage (Fig. 10b). These results thus confirm the findings from the DESI images. 

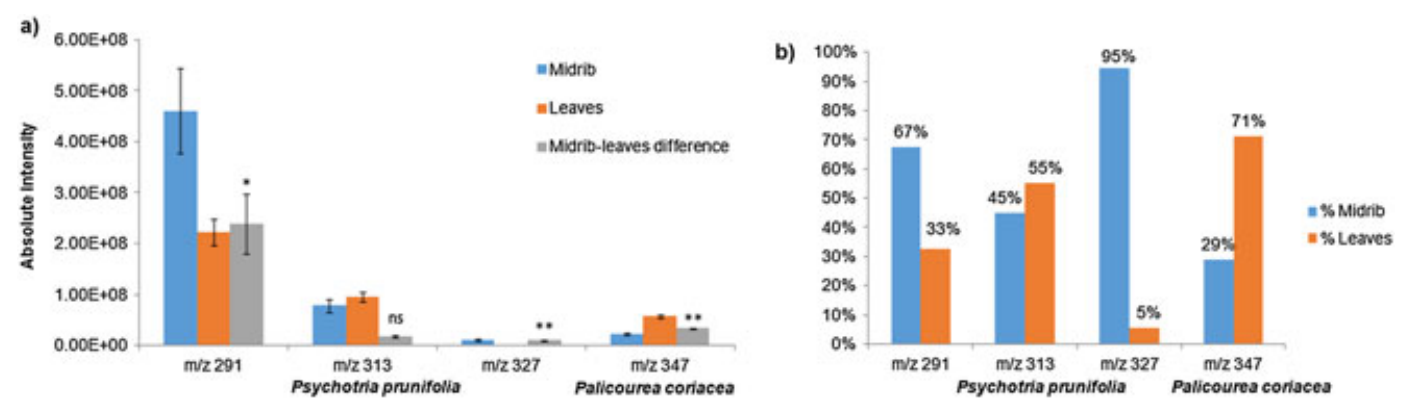

Figure 10. (a) Results of HPLC-MS analysis for the experiment separating the midrib from the leaves. Errors bars are standard deviations $(n=3)$. Asterisks indicate midrib-leaves differences that are significantly greater than zero at *95\% or **99\% confidence level, as calculated using a one-tailed Student's test. $\mathrm{ns}=$ no significant treatment effect. (b) Results of LC-MS analysis for the experiment as a percentage. [Colour figure can be viewed at wileyonlinelibrary.com]

\section{Acknowledgements}

L.K. wishes to thank the Conselho Nacional de Pesquisa e Desenvolvimento (CNPq) for granting a postdoctoral fellowship (247870/2013-7) and FAPEG to financial support (20121026700895), and A.P.M. wishes to thank the Coordenação de Aperfeiçoamento de Pessoal de Nível Superior (Capes) for granting a PhD sandwich fellowship (BEX 3088/14-6). The authors are grateful to Professor Sergio T. Sibov for the sample collection and to Professors Heleno Dias Ferreira and Helder Nagai Consolaro for the identification of vegetal samples.

\section{References}

Calixto NO, Pinto MEF, Ramalho SD, Burger MCM, Bobey AF, Young MCM Bolzani VS, Pinto AC. 2016. The genus Psychotria: Phytochemistry, chemotaxonomy, ethnopharmacology and biological properties. J Braz Chem Soc 27(8): 1355-1378.

da Silva VC, de Carvalho MG, Alves AN. 2008. Chemical constituents from leaves of Palicourea coriacea (Rubiaceae). J Nat Med 62: 356-357.

Delprete, P.G. 2010. Rubiaceae - Parte 2: Gêneros I-R (first edition) Flora dos estados de Goiás e Tocantins: Goiânia; IRD/ UFG, 581-1097.

do Nascimento CA, Gomes MS, Lião LM, de Oliveira CMA, Kato L, da Silva CC, Tanaka CMA. 2006. Alkaloids from Palicourea coriacea (Cham.) K. Schum. Z. Naturforsch B 61: 1443-1446.

Faria EO, Kato L, de Oliveira CMA, Carvalho BG, Silva CC, Sales LS, Schuquel ITA, Silveira-Lacerda EP, Delprete PG. 2010. Quaternary $\beta$-carboline alkaloids from Psychotria prunifolia (Kunth) Steyerm. Phytochem Lett 3: 113-116.

Furr M, Mahlberg PG. 1981. Histochemical analyses of laticifers and glandular trichomes in Cannabis sativa. J Nat Prod 44: 153-159.

Janfelt C. 2015. Imaging of plant materials using indirect desorption electrospray ionization mass spectrometry. Methods Mol Biol 1203: 91-97.

Kato L, de Oliveira CMA, Faria EO, Ribeiro LC, Carvalho BG, da Silva CC, Schuquel ITA, Santin SMO, Nakamura CV, Britta EA, Miranda N, Iglesias AH, Delprete PG. 2012. Antiprotozoal alkaloids from Psychotria prunifolia (Kunth) Steyerm. J Braz Chem Soc 23: 355-360.
Klein-Junior LC, Passos CS, Moraes AP, Wakui VG, Konrath EL, Nurisso A, Carrupt PA, de Oliveira CMA, Kato L, Henriques AT. 2014. Indole alkaloids and semisynthetic indole derivatives as multifunctional scaffolds aiming the inhibition of enzymes related to neurodegenerative diseases - a focus on Psychotria L. genus. Curr Top Med Chem 14: 1056-1075.

Klinkert I, Chughtai K, Ellis SR, Heeren RM. 2014. Methods for full resolution data exploration and visualization for large 2D and 3D mass spectrometry imaging datasets. Int J Mass Spectrom 362: 40-47.

Lee YJ, Perdian DC, Song Z, Yeung ES, Nikolau BJ. 2012. Use of mass spectrometry for imaging metabolites in plants. Plant J 70: 81-95.

Passos CS, Simões-Pires CA, Nurisso A, Soldi TC, Kato L, de Oliveira CM, Faria EO, Marcourt L, Gottfried C, Carrupt P, Henriques AT. 2013. Indole alkaloids of Psychotria as multifunctional cholinesterases and monoamine oxidases inhibitors. Phytochemistry 86: 8-20.

Rivier L, Lindgren JE. 1972. "Ayahuasca," the South American hallucinogenic drink: An ethnobotanical and chemical investigation. Econ Bot 26: 101-129.

Schramm T, Hester A, Klinkert I, Both JP, Heeren RM, Brunelle A, Laprévote O, Desbenoit N, Robbe MF, Stoeckli M, Spengler B, Römpp A. 2012. ImzML - A common data format for the flexible exchange and processing of mass spectrometry imaging data. J Proteome 75: 5106-5110.

Takáts Z, Wiseman JM, Gologan B, Cooks RG. 2004. Mass spectrometry sampling under ambient conditions with desorption electrospray ionization. Science 306: 471-473.

Taylor CM. 2015. Rubiacearum americanarum magna hama pars XXXIV: The new group Palicourea sect. Tricephalium with eight new species and a new subspecies (Palicoureeae). Novon: A Journal for Botanical Nomenclature 24: 55-95.

Thunig J, Hansen SH, Janfelt C. 2011. Analysis of secondary plant metabolites by indirect desorption electrospray ionization imaging mass spectrometry. Anal Chem 83: 3256-3259.

Yang H, Zhang H, Yang C, Chen Y. 2016. Chemical constituents of plants from the genus Psychotria. Chem Biodivers 13: 807-820.

Zhang J-W, Gao J-M, Xu T, Zhang X-C, Ma Y-T, Jarussophon S, Konishi Y. 2009. Antifungal activity of alkaloids from the seeds of Chimonanthus praecox. Chem Biodivers 6: 838-845. 